\title{
Andrzej Niezgoda
}

Maria Curie-Skłodowska University in Lublin, Poland

ORCID: 0000-0002-0664-2720

andrzej.niezgoda@umcs.pl

\section{Judicial Review of Taxation Authorities' Decisions on Reliefs in Payment of Tax Liabilities Based on Administrative Discretion}

\author{
Sądowa kontrola decyzji organów podatkowych w sprawach \\ ulg w spłacie zobowiązań podatkowych opartych na uznaniu \\ administracyjnym
}

\section{ABSTRACT}

The article is of a scientific-research nature. The author discusses the problem of limits of judicial review of discretionary decisions made by taxation authorities, which aim at applying relief in payments of tax liabilities under Polish regulations and case-law of administrative courts. It may be noted that despite the issue of administrative discretion being discussed in the academic literature, the question of limits of judicial review in the practice of administrative courts still raises doubts. It is therefore reasonable to undertake the analysis of the main views formulated in the literature and the case-law of administrative courts addressing this problem, from the point of view of the limits of judicial review of discretionary decisions. The thesis of the article is that the nature of discretionary decisions on relief in payment of tax liabilities, determined by the function of administrative discretion, and, at the same time, the criteria set out in the law for judicial review of public administration, limit the role of the administrative court in examining the compliance with procedural law of the tax proceedings preceding the issuance of such a decision and the respecting by tax authorities of the fundamental values of the system of law expressed in the Polish Constitution. This is because they define the limits of administrative discretion, within which the choice of one of the possible solutions remains beyond the judicial review of the public administration. For the law, as it stands (de lege lata) there are no grounds for administrative courts, provided that the tax authorities respect the basic values of the legal system expressed in the Polish Constitution, to formulate assessments as

CORRESPONDENCE ADDRESS: Andrzej Niezgoda, PhD, Dr. habil., Associate Professor, Maria Curie-Skłodowska University (Lublin), Faculty of Law and Administration, Institute of Law, Plac Marii Curie-Skłodowskiej 5, 20-031 Lublin, Poland. 
to the circumstances and reasons justifying the granting or refusal to grant a tax relief, or its scope. The concept of internal and external limits of administrative discretion may therefore be useful for administrative court rulings.

Keywords: discretionary decisions; limits of judicial review of discretionary decisions; taxation authorities; procedural law; administrative discretion

\section{INTRODUCTION}

The function of administrative judiciary, in accordance with Article 184 of the Polish Constitution, ${ }^{1}$ consists primarily in the review of public administration activity as regards compliance with law, ${ }^{2}$ i.e. both the compliance with formal law of the entire course of administrative proceedings and the correctness of the application of substantive law. ${ }^{3}$ Therefore, when the court hearing an action against decisions made in administrative proceedings, as well as against acts or activities of public administration (referred to in Article $3 \S \S 2$ to 3 LPAC), evades the duty to perform the review in question or performs it using criteria other than compliance with the law, goes beyond the systemic framework of the operation of administrative courts, violating Article $1 \S 2$ LSAC and Article $3 \S 1$ LPAC. ${ }^{4}$ In view of the above-mentioned provisions, the responsibility of administrative courts is solely the review of the challenged act in terms of compliance with law, but does not include examination in terms of purposefulness and rightness. ${ }^{5} \mathrm{An}$ administrative

${ }^{1}$ Constitution of the Republic o Poland of 2 April 1997 (Journal of Laws 1997, no. 78, item 483, as amended). English translation of the Constitution at: www.sejm.gov.pl/prawo/konst/angielski/ kon1.htm [access: 8.07.2021].

2 As provided for in Article $1 \S \S 1$ and 2 of the Act of 25 July 2002 - Law on the System of Administrative Courts (Journal of Laws 2021, item 137), hereinafter: LSAC. As pointed out in the literature, this provision sets the systemic boundaries for the functioning of administrative courts. Cf. R. Hauser, A. Kabat, Właściwość sądów administracyjnych, "Ruch Prawniczy, Ekonomiczny i Socjologiczny" 2004, no. 2, p. 25.

${ }^{3}$ Which results from the content of Article $145 \S 1$ of the Act of 30 August 2002-Law on Procedure Before Administrative Courts (Journal of Laws 2019, item 2325, as amended), hereinafter: LPAC.

${ }^{4}$ Cf. judgement of the Supreme Administrative Court of 6 December 2018, I FSK 1369 (unless specified otherwise, all the cited judgements of administrative courts are downloaded from the Central Database of Administrative Court Judgements). The regulations of the Law on the System of Administrative Courts and the Law on Procedure Before Administrative Courts mentioned above are the consequence of basing the political system of the Republic of Poland on the separation and balance between the legislative, executive and judicial powers and on conferring upon the courts and tribunals only the judicial power. Legislative power is exercised by the Polish Sejm and the Senate, while the executive power is exercised by the President of the Republic of Poland and the Council of Ministers. See Article 19 of the Polish Constitution.

${ }^{5}$ Cf. judgement of the Supreme Administrative Court of 26 January 2006, II OSK 630/05; judgement of the Supreme Administrative Court of 30 May 2018, II FSK 3783/17. 
court's analysis of the purposefulness or rightness of the decision under review would mean encroaching on the powers of the relevant administrative authorities and interfering in their policies. ${ }^{6}$ For this reason, the adjudicatory powers of administrative courts, arising from the content of Article $145 \S 1$ LPAC are generally of a cassation nature. Therefore, the courts may not rule on the merits of the case concerning the challenged act, but only uphold the challenged act or eliminate it from legal transactions if it is contrary to law. ${ }^{7}$

It is noted in the literature, however, that even within such limits of functioning, when reviewing the act being challenged, the court of first instance creates an idea of a defined, lawful decision as a benchmark to compare with the challenged act. ${ }^{8}$ It is also pointed out that the problem of review of the legality of activities of the public administration by administrative courts, i.e. drawing the demarcation line between the exercise of executive and judicial powers raises many questions and doubts. One concept is that administrative courts taking decisions of a reformatory nature when certain conditions are met does not infringe the principle of separation of powers, as it is the duty of the court to remedy the infringement by the simplest means available. ${ }^{9}$ According to this concept, as a result of the amendment of the Law on Procedure Before Administrative Courts in 2015, Polish administrative courts were given the power to require the authority, where justified by the circumstances of the case, to issue a decision or order within a specified period, while also specifying the manner in which the case was to be settled or resolved. ${ }^{10}$

This problem was noticed in the literature with the appearance of judicial review of activity of the public administration. However, due to the changing paradigm of judicial review of the public administration, this problem is still valid and requires more research. This paper aims to analyse the main theses put forward in the literature on the subject and the case-law of administrative courts addressing this problem, from the point of view of the limits of judicial review of discretionary decisions. The article does not address the issue of the relationship between the content of Articles 67a and 67b of the Tax Ordinance, which requires a separate study due to the divergence of views expressed in this regard in the case-law of the Polish Supreme Administrative Court.

\footnotetext{
${ }^{6}$ Cf. judgement of the Supreme Administrative Court of 5 September 2019, I OSK 1419/18.

${ }^{7}$ Cf. J.P. Tarno, Prawo o postepowaniu przed sądami administracyjnymi. Komentarz, Warszawa 2006, p. 309.

${ }^{8}$ Cf. T. Woś (ed.), H. Knysiak-Molczyk, M. Romańska, Ustawa o postępowaniu przed sądami administracyjnymi. Komentarz, Warszawa 2012, p. 724 and the literature referred to therein.

${ }^{9}$ Cf. Z. Kmieciak, Zarys teorii postępowania administracyjnego, LEX/el. 2014.

10 See Article 145a $\S 1$ LPAC, added by Article 1 (38) of the Act of 9 April 2015 amending the Act - Law on Procedure Before Administrative Courts (Journal of Laws 2015, item 658), as of 15 August 2015.
} 


\section{ADMINISTRATIVE DISCRETION AND FLEXIBILITY OF OPERATION OF TAXATION AUTHORITIES}

The legislation does not define administrative discretion. However, it can be assumed that administrative discretion, which ensures flexibility in the operation of public administration bodies and allows them to achieve economic, social and fiscal objectives, means the power to form a legal relationship according to the administrative authority's own assessment of rightness or purpose, by choosing one of the alternative legal consequences of the facts established. Discretion is therefore part of the legal norm and occurs at the last stage of the application of law.

The flexibility of operation of public administration resulting from a certain margin of discretion in applying the law is manifested at almost all stages of the application of law. A validation decision has a strict (non-discretionary) norm. However, the law-applying public administration body has a certain scope of freedom in making an interpretative decision, depending on the adopted concept of interpretation. Generally speaking, the static theory of legal interpretation, which assumes the primacy of the linguistic method, leaves less freedom than the dynamic theory, which opens up to functional and teleological methods of interpretation. At the stage of establishing facts of the case, the lack of being bound by rigid rules, though not arbitrariness, results from the principle of free assessment of evidence. ${ }^{11}$ At the stage of legal assessment of the established facts, the freedom of decision may result from the intended ambiguity of the legal norm designed as such by the lawmakers through the use of general clauses or estimative expressions, as in Article 67a of the Tax Ordinance, ${ }^{12}$ "public interest" and "important interest of the taxpayer", the meaning of which is explained in the context of a specific factual state. Their use allows the achievement of various taxation objectives, while respecting the principle of exclusivity of statutory provisions in the field of imposing and shaping the structure of public levies, by ensuring the necessary flexibility of legal regulation. ${ }^{13}$

The main purpose of the use of discretion is to enable public administration bodies to issue decisions taking into account different reasons and values, ${ }^{14}$ and

${ }^{11}$ Cf. A. Hanusz, Podstawa faktyczna decyzji podatkowej a swobodna ocena dowodów, [in:] Pro publico bono. Regulacje prawno-podatkowe i rozwiazania finansowe. Ksiega jubileuszowa Profesora Jana Gluchowskiego, Torun 2002, p. 95; L. Leszczyński, Open Axiology in Judical Interpretation of Law and Possible Misuseof Discretion, "Studia Iuridica Lublinensia" 2020, vol. 29(3), p. 43.

12 Act of 29 August 1997 - Tax Ordinance (Journal of Laws 2020, item 1235, as amended).

${ }_{13}$ Cf. P. Borszowski, Określenia nieostre i klauzule generalne w prawie podatkowym, Warszawa 2017, p. 140.

${ }^{14}$ G. Pesce, Discretionary Power of Public Administration and Control of Public Debt: The Citizen and the Judge between the Law and the Precedent, "Studia Iuridica Lublinensia" 2020, vol. 29(3), p. 117. 
consequently, as mentioned above, flexibility of operation. Legal norms which contain a reference to administrative discretion are opposite to strict norms binding in a given decision. Strict norms do not leave public administration bodies, at the stage of establishing legal consequences of the factual state, any margin of discretion in adopting administrative acts, depriving them of the possibility to choose a specific rule of proceeding on their own.

Undoubtedly, the review of discretionary decisions by the administrative court proves to be difficult. Apart from the above-mentioned issue, directly related to the scope of adherence by the court to its responsibilities, i.e. the exercise of review of decisions made by public administration only according to the criterion of compliance with law, it should be noted that the court may not have enough knowledge needed to assess the reviewed decision from the point of view of rightness or purposefulness. which may not be apparent from the case file. ${ }^{15}$ As regards decisions of taxation authorities of local government units based on administrative discretion, it should also be noted that making such decisions is a manifestation of the implementation of an independent social, economic or fiscal policy by local government units. ${ }^{16}$ Pursuant to Article 165 (2) of the Polish Constitution, independence of local government is subject to judicial protection. Therefore, the administrative court should not narrow it down by applying criteria other than compliance with the law, to assess discretionary decisions on local government tax relief. During the Second Polish Republic, the legislature eliminated these difficulties, expressly excluding from the competence of the Supreme Administrative Tribunal any cases in which administrative bodies were entitled to decide at their discretion, within the margin left to this discretion. ${ }^{17}$

The nature of discretionary decisions concerning the application of tax relief in the payment of tax liabilities determined by the function of administrative discretion and at the same time the statutorily defined criteria for judicial review of the public administration raise a question as to the scope of judicial review of decisions of this type. It seems justified to claim that the role of the administrative court is limited to examining the compatibility of the tax proceeding with procedural law and the respecting by the tax authorities of the fundamental values of the system of law, as expressed in the Polish Constitution. This is because they outline the framework of

${ }^{15}$ For example, related to collecting revenues as a source of financing public tasks which is a basis for developing directives for the fiscal policy.

${ }^{16}$ One of guarantees of this independence of local government is the limitation of powers of the local government board of appeal, resulting from Article $233 \S 3$ of the Tax Ordinance, which board of appeal, when accepting an appeal against a decision of the local government tax authority, may only issue a cassation decision.

17 See Article 6 (2) of the Regulation of 27 October 1932 on the Supreme Administrative Tribunal (Journal of Laws 1932, no. 94, item 806). 
administrative discretion, within which the choice of one of the possible solutions remains beyond the judicial review of the public administration.

The understanding of the concept of discretion in the science of administrative law has evolved. ${ }^{18}$ This also concerned the question of the scope of freedom and binding those authorities with law. Initially, in the perspective of naturalistic concepts, it was assumed that discretion existed outside the realm of legal regulation, which was relatively narrow at that time. It used to be claimed that the public administration could generally operate freely unless its activities had been regulated to a certain extent by law. ${ }^{19}$ It was also pointed out that the public administration was not, by its very nature, limited to the execution of laws, since it was established to act creatively, outside the scope of the statutory provisions. ${ }^{20}$ The administrative body may therefore also take a decision where the law is silent, provided that this does not prejudice the public interest or interest of the individual. ${ }^{21}$

On the other hand, in the perspective of positivistic concepts, discretion needs a statutory authorisation, a kind of "power of attorney" from the legislature. However, using the discretion granted by the law, the authority operates in a legally unregulated area. Therefore discretion, which is a specific type of authorisation under the administrative law, ${ }^{22}$ consists of the possibility for a public authority to act on its own, but within statutory limits. ${ }^{23}$

The essence of modern views on administrative discretion is the assumption that every intervention of the public administration in the individual sphere of the citizen must have a clear, specific, statutory basis ${ }^{24}$ and that the actions of the administration must remain within the limits of the law. Where legal norms do not expressly provide for the competence of a public authority, that competence cannot be presumed. ${ }^{25}$ This is expressed in Article 7 of the Polish Constitution, according to which the organs of public authority function on the basis of, and within the limits of, the law. This provision sets the absolute limits beyond which there is lawlessness. ${ }^{26}$ Thus, there is only such discretion and only within such limits as the legislature may prescribe in a given case. Discretion is therefore a strictly defined

${ }^{18}$ Cf. M. Mincer, Uznanie administracyjne, Torun 1983, p. 8 ff.

19 J. Starościak, Swobodne uznanie władz administracyjnych, Warszawa 1948, p. 89.

20 W.L. Jaworski, Nauka prawa administracyjnego. Zagadnienia ogólne, Warszawa 1924, pp. $123-126$.

${ }^{21}$ J.S. Langrod, Zagadnienia wybrane z praktyki administracyjnej, Kraków 1938, pp. 91-93.

22 W. Reiss, Prawo administracyjne w zarysie, part 1: Nauka administracji, Toruń 1946, p. 114, 126.

23 S. Kasznica, Polskie prawo administracyjne. Pojęcia i instytucje zasadnicze, Poznań 1947, pp. 133-134.

${ }^{24}$ M. Zimmermann, Pojęcie administracji publicznej a swobodne uznanie, Warszawa 2009, pp. 13-14.

${ }^{25}$ Cf. judgement of the Constitutional Tribunal of 10 May 1994, W 7/94, OTK 1994, no. 1, item 23.

${ }^{26}$ R. Gałęski, Zakres swobody organu administracji publicznej w podejmowaniu czynności faktycznych, "Przegląd Prawa i Administracji” 2002, no. 51, p. 192. 
area of freedom granted to the public administration by the legislature, but does not imply the right to any arbitrary action. ${ }^{27}$ The authorisation for administrative discretion is a specific and unique way of shaping the competence of a public authority in the content of a legal norm. ${ }^{28}$ It consists of the possibility for the public authority to choose one of several equivalent legal consequences of a given factual situation.

In a legal norm, that authorisation to choose the legal consequences of the facts established is contained in its part referred to as disposition of the norm. ${ }^{29}$ The part referred to as the hypothesis defines in addition to the addressee of the norm, the circumstances in which it applies, while the disposition delimits the scope of regulation, that is the required or prohibited conduct. This part of the legal nor therefore gives the public administration body the option to choose between two or more legal consequences. ${ }^{30}$ It may also be noted that the authorisation for discretion, but expressed in the hypothesis of a legal norm, occurs when the hypothesis of the norm is imprecise or absent. ${ }^{31}$ An example of a norm with such structure may be the norm resulting from the content of Article 18 of the Polish Citizenship Act, ${ }^{32}$ pursuant to which the President of the Republic of Poland may grant Polish citizenship to a foreigner.

Nonetheless, it should be stressed that Article 67a $\S 1$ of the Tax Ordinance is structured differently. It is possible to decode from this provision a norm, which requires the taxation authorities to grant at the request of a taxpayer a tax relief in cases justified by an important interest of the taxpayer or the public interest (hypothesis), i.e. to defer the date of tax payment or spread the payment of tax into instalments, to defer or spread into instalments the payment of tax arrears with interest for late payment or interest on outstanding tax advances, to cancel, in whole or in part, tax arrears, interest for late payment or prolongation fee or to refuse to grant the relief (disposition). In this case, discretion entails determining the legal consequences of the factual state and consists in the possibility for the tax authority to choose one of several legally equivalent consequences of this factual state. Such position of administrative discretion in the structure of the legal norm constituting the basis for granting tax reliefs was supported by the Supreme Administrative Court when

27 Z. Janowicz, Kodeks postępowania administracyjnego. Komentarz, Warszawa 1999, p. 305.

28 A. Nałęcz, Uznanie administracyjne a reglamentacja działalności gospodarczej, Warszawa 2010, p. 35 .

29 T. Bigo, Kontrola uznania administracyjnego, "Sprawozdania Wrocławskiego Towarzystwa Naukowego" 1959, no. 14A, p. 55; M. Mincer, op. cit., p. 52.

${ }^{30}$ A. Nałęcz, op. cit., p. 41 and the literature referred to therein, including I. Bogucka, Państwo prawne a problem uznania administracyjnego, "Państwo i Prawo" 1991, no. 14, p. 40 and M. Mincer, op. cit., p. $52 \mathrm{ff}$.

${ }^{31}$ W. Lang, A. Delorme, Z zagadnień tzw. swobodnego uznania (w zwiazku z wprowadzeniem sadowej kontroli administracji), "Państwo i Prawo" 1957, no. 4-5, p. 747.

32 Act of 2 April 2009 on Polish citizenship (Journal of Laws 2020, item 347). 
it stated that the expressions "important interest of the taxpayer" and "the public interest", referring to the hypothesis of the norm, point to the factual situation in which tax arrears or default interest may be forgiven. The taxation authority has a certain margin of freedom in both the interpretation of those terms and the assessment of the factual situation. This freedom in respect of the interpretation of vague terms and assessment of the factual situation cannot be equated with administrative discretion. Discretion, i.e. the application of the disposition of a legal norm, takes place when the taxation authority finds that there is one of these prerequisites or both of them jointly. ${ }^{33} \mathrm{On}$ the other hand, if the authority finds the prerequisites of "important interest of the taxpayer" or "public interest" non-existent, the authority will not have an option to choose and the decision will be of a strict nature. ${ }^{34}$

This way of approach to Article 67a $\S 1$ of the Tax Ordinance determines two phases of tax proceedings. In the first phase, the taxation authority must determine whether at least one of the prerequisites for the application of relief ("important interest of the taxpayer", "public interest") exists, which requires gathering evidence necessary for these findings, and its proper evaluation. If it is established that one or both of the prerequisites are fulfilled, the proceedings move to the second phase in which the taxation authority, exercising its administrative discretion, chooses whether to grant or refuse the relief. Thus, if the authority finds and assesses that an important interest of the taxpayer or the public interest does not exist in the given case, it will not be entitled to apply tax relief. ${ }^{35}$

\section{LIMITS OF ADMINISTRATIVE DISCRETION AND JUDICIAL REVIEW OF DISCRETIONARY DECISIONS}

With the development of the positivist concept of administrative discretion, which assumes that discretion requires a detailed legal basis, a reflection was also undertaken on the limits of discretion and judicial review of discretionary activities of the public administration. The external and internal boundaries of discretion were then distinguished. External boundaries are delimited by law. Internal boundaries are non-legal and are related to motivation of the authority concerned. ${ }^{36}$ At the same time, it was assumed that only the infringement of external boundaries had legal relevance. The administrative court is therefore entitled only to examine whether the authority has exceeded the external limits of its discretion or not. On the other

\footnotetext{
33 Judgement of the Supreme Administrative Court of 26 August 2010, II FSK 689/09.

34 Judgement of the Supreme Administrative Court of 16 March 2006, II FSK 493/05.

35 Judgement of the Supreme Administrative Court of 29 May 2018, II FSK 1431/16.

36 T. Hilarowicz, Najwyższy Trybunat Administracyjny i jego kompetencja, Warszawa 1925,
} pp. 230-231; J. Starościak, op. cit., p. 92 ff. 
hand, the question of respecting internal boundaries falls outside the scope of judicial review. This concept is based on the above-mentioned regulation of the scope of review of activity of the public administration by the Supreme Administrative Tribunal, which excludes judicial review of the operation of the administrative authorities within the limits left to discretion.

After the reinstatement of administrative jurisdiction in Poland, the Supreme Administrative Court did not take up the concepts of external and internal boundaries of discretion. Instead, in the judgement of June 1981, th Court took the view that the authority which takes a discretionary decision is limited in the choice of legal consequences by the general principle of taking into account the public interest and the legitimate interest of the citizens. The authority is therefore obliged to settle the case positively or the party if this does not contradict the public interest and does not exceed the possibilities of the authority to exercise the powers potentially conferred. ${ }^{37}$ That view was an expressis verbis reproduction of the content of Article 7 of the Code of Administrative Procedure, ${ }^{38}$ in the wording given to it a few months earlier. ${ }^{39}$ This ruling, by indicating the criteria to be followed by the public authority when deciding within the external boundaries of its discretion or, in other words, assuming that those criteria are of a normative nature, gave rise to judicial review of the conditions for the public administration to choose from among various consequences of the factual state specified by the legal norm. ${ }^{40}$ It also states that the criteria for the selection of legal consequences may be laid down in provisions other than those of substantive law, which form the basis for action of the public authority and which include the authorisation for administrative discretion. According to the view proposed in that judgement, the concretisation of a norm containing an authorisation for administrative discretion may be lawfully assessed in a given factual state in the light of a proper interpretation of the terms

${ }_{37}$ Judgement of the Supreme Administrative Court of 11 June 1981, SA 820/81, ONSA 1981, no. 1 , item 57.

38 Act of 14 June 1960 - Code of Administrative Procedure (Journal of Laws 2021, item 735).

39 By Article 11 of the Act of 31 January 1980 on the Supreme Administrative Court and on the amendment of the Act Code of Administrative Procedure (Journal of Laws 1980, no. 4, item 8), as of 1 September 1980.

${ }^{40}$ It should be noted that Article 122 of the Tax Ordinance, which is the "equivalent" of the aforementioned Article of the Code of Administrative Procedure, does not formulate a general rule to be guided, when hearing each tax case, by the values resulting from the indicated or similar general clauses. Given the systemic and economic sense of taxation (tax is an individual sacrifice for a collective purpose) the taxation authority should take into account the public interest and the legitimate interest of the taxpayer when making tax-law decisions. This is a political-systemic duty. Moreover, as further discussed, in the legal regulation forming a basis for granting tax relief using administrative discretion, those clauses constitute, as an element of the hypothesis of a legal norm, the basis for the legal assessment of the facts and not the directive on the choice of the consequences in the form of the grant or refusal of the tax relief. 
"public interest" and "legitimate interest of the citizen" in only one way. Other potential possible choices, in the light of the provision which is the direct basis for the activity of the administrative authority, will be unlawful.

In the literature, however, an opinion was presented that even when the disposition of the norm entitles to using discretion, the hypothesis may contain the indication of such factual circumstances that the authority will not be able to choose the legal consequence, but its decision will be of a strict nature. The circumstances indicated in the hypothesis will in fact constitute directives for the choice of legal consequences ${ }^{41}$ Deeming the prerequisites of the public interest or important interest of the taxpayer as directives for the choice of legal consequences is also present in the case law. ${ }^{42}$ Such a view does not seem accurate with regard to discretionary decisions on tax reliefs. This follows from the above-quoted wording of the provision of Article $67 \mathrm{a} \S 1$ of the Tax Ordinance, which formulates the basis for discretionary decisions on granting tax reliefs. Indeed, if one were to share the argumentation presented above that the circumstances indicated in the hypothesis constitute directives for the choice of legal consequences and, therefore, the decision of the taxation authority on the application of the relief would be of a strict nature, then one would have to assume that the phrase: "the tax authority ... in cases justified by the public interest or an important interest of the taxpayer, may defer/spread into instalments/cancel ..." is equivalent to the phrase: "in cases justified by the public interest or by the important interest of the taxpayer, the authority shall defer/spread into instalments/cancel ...". However, neither the rules of colloquial language nor the contents of the Tax Ordinance do not authorise this. Also in the literature on the subject, both older and current, it is indicated that one form of authorisation to discretion is the use of the phrase in the legal text: "the authority may" take a decision of a certain content. ${ }^{43}$ This understanding of the formula contained in Article 67a of the Tax Ordinance was presented by the Supreme Administrative Court which assumed that a public administration body, after a comprehensive examination of the facts and finding that at least one of the prerequisites included in the hypothesis of the norm, i.e. that the public interest or an important interest of the taxpayer justifies the application of the tax relief, may either issue a positive decision for the party or refuse to grant such relief. ${ }^{44}$ On the other hand, if the taxation authority finds the prerequisites of "important interest of the taxpayer" or "public interest" non-existent in the application of the

\footnotetext{
${ }^{41}$ A. Habuda, Granice uznania administracyjnego, Opole 2004, p. 65 ff.

${ }^{42}$ Judgement of the Supreme Administrative Court of 15 March 2013, II FSK 1535/11; judgement of the Supreme Administrative Court of 26 June 2019, II FSK 2414/17.

${ }^{43}$ M. Jaroszyński, M. Zimmermann, W. Brzeziński, Polskie prawo administracyjne. Część ogólna, Warszawa 1956, p. 359; J. Borkowski, Decyzja administracyjna, Łódź-Zielona Góra 1998, p. 80.

44 Judgement of the Supreme Administrative Court of 31 January 2006, I FSK 570/03; judgement of the Supreme Administrative Court of 30 October 2009, I FSK 804/08.
} 
tax relief, the authority will not have an option to choose and the decision will be of a strict nature. ${ }^{45}$

It should be accepted that for that very reason general clauses or phrases defining compliance with the norm formulated in the hypothesis of the norm, which determine its scope of application, constitute a restriction on the freedom of action of the body applying the legal norm containing the authorisation to discretion. It should be stressed, however, that they equally restrict the body applying a norm that does not include authorisation for discretion. This is due to the function of hypothesis of the legal norm. It defines, as mentioned earlier, the class of conduct (situation) in which the norm applies. Such a restriction cannot, therefore, be regarded as typical of discretionary decisions or as a directive for the discretionary choice of legal consequences.

In view of the above-mentioned understanding of administrative discretion, which consists in the possibility for a public authority to choose one of the legally equivalent consequences of a given factual situation, and disregarding what is linked to the application of law in general and not specific to discretion but also applies to discretionary decisions, it must be concluded that there are two types of limits of discretion. ${ }^{46}$ First, the limits of discretion determine the consequences of facts described in the disposition of a legal norm. As part of discretion, the authority may only choose between the legal consequences laid down by law and not any consequences. Referring this to the provisions authorizing discretionary decisions in matters of tax credits, two legal consequences can be observed in establishing that the granting of the tax relief is justified by the public interest or an important interest of the taxpayer. In such a situation, the authority may either grant or refuse the relief. Moreover, the limits of discretion are set by the taxpayer's request indicating the type of relief sought by the taxpayer.

Secondly, the limits of discretion define the circumstances which the authority is required to take into account when choosing one of the several legal consequences referred to in the disposition of the legal norms, namely the directive on the choice of consequences. These are the values or objectives that the body should be guided by when choosing the legal consequences. They may be articulated in the wording of the provision containing an authorisation for discretion or not. ${ }^{47}$

Article 67a of the Tax Ordinance, which includes the authorisation for discretion in deciding on the granting of tax reliefs, does not formulate directives for the selec-

45 Judgement of the Supreme Administrative Court of 16 March 2006, II FSK 493/05.

46 A. Nałęcz, op. cit., p. 80 ff.

47 This is the case, e.g., in Article $18 \mathrm{c} \S \S 1$ and 2 of the Tax Ordinance, pointing to the objective of streamlining and speeding up tax audit or tax proceedings, as a directive for the choice of consequences in the form of the designation or non-designation of a single taxation authority as competent to carry out the audit or proceedings in cases concerning taxpayers located within the jurisdiction of different authorities. 
tion of consequences. However, the literature has presented the view that directives for the selection of legal consequences may result from the Polish Constitution as well as from procedural rules. ${ }^{48}$ The Supreme Administrative Court also took the position that the decision concerning the tax relief cannot be arbitrary. According to Article 7 of the Polish Constitution and Article 120 of the Tax Ordinance, public authorities are obliged to act on the basis of law and within the limits of law. In the case of administrative discretion, the absence of clear legal rules determining the outcome does not mean that the decision of the authority may be abstracted from any legal criteria. Considerations of rightness and purposefulness in choosing the decision option must, in parallel, take into account the need for the authority to implement constitutional values and norms. ${ }^{49}$

Administrative courts, when reviewing decisions of taxation authorities in cases of reliefs based on administrative discretion, have often taken a position as to in what circumstances, for what reasons and to what extent the granting of relief would be justified, invoking the need to avoid the undesirable, from the social and individual points of view, effects of tax enforcement, ${ }^{50}$ exceptional nature of tax cancellation redemption as an inefficient form of expiry of tax liabilities, ${ }^{51}$ or finally the current financial and medical situation of the taxpayer. ${ }^{52}$ This current also includes judgements in which the court indicates that the authority should determine in each case what is more important from the point of view of the public

48 A. Błaś, Studia z nauki prawa administracyjnego i nauki administracji, "Acta Universitatis Wratislaviensis. Prawo" 1988, vol. 21, p. 47. In this context, it is worth noting the content of Article $8 \S 1$ of the Code of Administrative Procedure (in the wording effective since 1 June 2017), according to which public administration bodies shall conduct proceedings in a manner that inspires confidence of its participants in public authority, being guided by the principles of proportionality, impartiality and equal treatment. However, the literature, when commenting on the provision, points out that following the principles of proportionality, impartiality and equal treatment is a procedural obligation of any public administration body. This is indicated by the wording of the commented provision, which requires that these principles are followed in the course of "running" administrative proceedings by public administration bodies. It is, therefore, doubtful that the said principles have the character of directives for the interpretation and application of substantive law constituting the legal basis for resolving an administrative case. See A. Wróbel, [in:] M. Jaśkowska, M. Wilbrandt-Gotowicz, A. Wróbel, Komentarz aktualizowany do ustawy z dnia 14 czerwca 1960 r. - Kodeks postepowania administracyjnego, LEX/el 2019, thesis 11 of the commentary on Article 8. As a side note, it may be pointed out that Article $121 \S 1$ of the Tax Ordinance does not contain a similar reference.

49 Judgement of the Supreme Administrative Court of 6 October 2017, II FSK 2422/15.

50 Judgement of the Supreme Administrative Court of 26 June 2019, II FSK 2414/17.

${ }^{51}$ Judgement of the Supreme Administrative Court of 15 March 2013, II FSK 1535/11; judgement of the Supreme Administrative Court of 26 June 2019, II FSK 2414/17.

${ }^{52}$ Non-final judgement of the Voivodeship Supreme Administrative Court in Rzeszów of 2 July 2019, I SA/Rz 244/19. 
interest: granting or refusing to grant the relief, by weighing the values common to the whole society, such as fairness, ethical principles, trust in state authorities. ${ }^{53}$

Sometimes the administrative court did not positively formulate directives on the choice of legal consequences to be followed by the taxation authority when making decisions based on administrative discretion, but only pointed out that a choice made in gross violation of the principle of fairness would be unacceptable, as a result of taking into account obviously irrelevant (trivial) or irrational criteria, as well as on the basis of false premises (arguments that are not true). The court has also stressed that the cases of using this power by the tax authorities in an arbitrary, completely irrational manner, or contrary to basic constitutional principles, must not remain outside judicial review. ${ }^{54}$ Admittedly, if the conditions are met, the public administration body has the right, but not the obligation, to grant the relief. However, the decision of the body cannot be arbitrary, but must be the result of finding the facts of the case, a comprehensive collection and exhaustive consideration of the evidence material. ${ }^{55}$

One should also note rulings in which the Supreme Administrative Court stated that, once one of the conditions had been found to exist, it was for the tax administration body ${ }^{56}$ to choose the decision, and that the finding that the decision was not arbitrary, because it was based on the evidence gathered and its assessment, precluded interference by the court with the free choice made by the taxation authority ${ }^{57}$ It is not the administrative discretion as such that is subject to review, but the question of whether the decision was taken in accordance with the basic rules of administrative procedure and especially whether it was based on the evidence gathered in the case and whether the assessment of that evidence was carried out in accordance with the principle of the free assessment of evidence or whether it contained elements of arbitrariness. This means that even the authority finds all the prerequisites does not obligate it to grant the relief, but only gives the option to do so and to a limited extent that it is subject to judicial review. ${ }^{58}$

53 Judgement of the Supreme Administrative Court of 27 February 2013, II FSK 1351/11; judgement of the Supreme Administrative Court of 17 May 2017, II GSK 5349/16.

${ }^{54}$ Judgement of the Supreme Administrative Court of 29 May 2018, II FSK 1431/16.

55 Judgement of the Supreme Administrative Court of 13 November 2007, II FSK 1353/06; judgement of the Supreme Administrative Court of 29 June 2011, II FSK 227/10; judgement of the Supreme Administrative Court of 17 May 2017, II GSK 5349/16.

56 Judgement of the Supreme Administrative Court of 31 January 2006, I FSK 570/03; judgement of the Supreme Administrative Court of 30 October 2009, I FSK 804/08.

57 Judgement of the Supreme Administrative Court of 7 February 2001, I SA/Gd 1507/00.

58 Judgement of the Supreme Administrative Court of 7 February 2018, II FSK 3609/15. This judgement was issued in a case of exemption from enforcement against the assets of the person liable, pursuant to Article $13 \S 1$ of the Act of 17 June 1966 on enforcement proceedings in the public administration (Journal of Laws 2020, item 1427, as amended), which is structured similarly to Article 67a of the Tax Ordinance. 
It may be pointed out that in some European countries, the criteria for judicial review of decisions based on administrative discretion are generally laid down in the legal acts governing administrative proceedings. For example, the German Act on administrative judiciary of 1960 authorises the court to verify whether the administrative act under review falls within its statutory limits and whether the discretion was in a manner appropriate to the purpose of the authorisation. The Estonian Code of Procedure before Administrative Courts of 1999 obligates the court to assess, when examining the legality of an act of discretion, whether that act was adopted within the limits and in accordance with the purpose of the discretion and in accordance with the principles of proportionality, equality and other generally accepted principles of law. ${ }^{59}$ These criteria are similar to those specified in the case law of the Polish Supreme Administrative Court.

\section{CONCLUSIONS}

To sum up, it should be stated that in the content of the analysed legal regulation which governs the granting of tax reliefs, discretion occurs in the disposition of the norm and takes place at the stage of determining the legal consequences of facts of the case, when the authority selects one of the legally equivalent consequences of the established factual state. The authorisation resulting from the provisions of the Act to make decisions on tax reliefs with the application of discretion gives the tax authorities a space within which they implement economic, social or fiscal policies, which is within the scope of the executive authority's activities. The legislature, by granting tax authorities the power to decide on reliefs with the use of administrative discretion, did not expressly formulate directives on the choice of legal consequences. Clauses of public interest and important interest of the taxpayer, included in the hypothesis of the norm, which are the criteria for assessing the factual state, do not constitute such directives. Determining that the facts constitute a case justified by an important interest of the taxpayer or the public interest, obliges the taxation authority to consider whether to grant a relief or refuse it. Otherwise, the decision to refuse to grant the tax relief is of a strict nature.

The fact that the provision of the Tax Ordinance does not set out the criteria for selecting legal consequences does not mean that within the limits of the space left to the taxation authorities by applying administrative discretion, they may decide arbitrarily. It is aptly pointed out in the case-law of the Supreme Adminis-

59 S. Łajszczak, Rozwój procedur administracyjnych na tle standardów funkcjonowania władzy publicznej, [in:] Kierunki rozwoju prawa administracyjnego. Prace członków i Przyjaciół na 5-lecie Koła Naukowego Prawa Administracyjnego na Uniwersytecie Warszawskim, ed. R. Stankiewicz, Warszawa 2011, p. $106 \mathrm{ff}$. 
trative Court that decisions made by tax authorities with the use of administrative discretion in matters of tax relief, apart from teleological reasons resulting from the policy pursued, must also take into account the necessity to implement constitutional values and norms. For the law as it stands (de lege lata), however, it does not seem justified to derive directives on the choice of legal consequences from procedural provisions.

Due to the functions of administrative judiciary, the review of decisions of taxation authorities in cases of reliefs granted based on administrative discretion by administrative courts, covers only the examination of the compliance with procedural law, which should lead to a thorough clarification of the facts and formulation of its correct assessment from the point of view of public interest and important interest of the taxpayer. De lege lata, there are no grounds for administrative courts, provided that the taxation authorities respect the basic values of the legal system expressed in the Constitution, to formulate assessments as to the circumstances and reasons justifying the granting or refusal to grant a tax relief, or the scope of relief.

\section{REFERENCES}

\section{Literature}

Bigo T., Kontrola uznania administracyjnego, "Sprawozdania Wrocławskiego Towarzystwa Naukowego" 1959, no. 14A.

Błaś A., Studia z nauki prawa administracyjnego i nauki administracji, “Acta Universitatis Wratislaviensis. Prawo" 1988, vol. 213.

Bogucka I., Państwo prawne a problem uznania administracyjnego, "Państwo i Prawo"1991, no. 14. Borkowski J., Decyzja administracyjna, Łódź-Zielona Góra 1998.

Borszowski P., Określenia nieostre i klauzule generalne w prawie podatkowym, Warszawa 2017.

Gałęski R., Zakres swobody organu administracji publicznej w podejmowaniu czynności faktycznych, "Przegląd Prawa i Administracji" 2002, no. 51.

Habuda A., Granice uznania administracyjnego, Opole 2004.

Hanusz A., Podstawa faktyczna decyzji podatkowej a swobodna ocena dowodów, [in:] Pro publico bono. Regulacje prawno-podatkowe i rozwiązania finansowe. Księga jubileuszowa Profesora Jana Gtuchowskiego, Torun 2002.

Hauser R., Kabat A., Właściwość sądów administracyjnych, "Ruch Prawniczy, Ekonomiczny i Socjologiczny" 2004, no. 2.

Hilarowicz T., Najwyższy Trybunat Administracyjny i jego kompetencja, Warszawa 1925.

Janowicz Z., Kodeks postępowania administracyjnego. Komentarz, Warszawa 1999.

Jaroszyński M., Zimmermann M., Brzeziński W., Polskie prawo administracyjne. Czesść ogólna, Warszawa 1956.

Jaworski W.L., Nauka prawa administracyjnego. Zagadnienia ogólne, Warszawa 1924.

Kasznica S., Polskie prawo administracyjne. Pojęcia i instytucje zasadnicze, Poznań 1947.

Kmieciak Z., Zarys teorii postepowania administracyjnego, LEX/el. 2014.

Lang W., Delorme A., Z zagadnień tzw. swobodnego uznania (w związu z wprowadzeniem sądowej kontroli administracji), "Państwo i Prawo" 1957, no. 4-5. 
Langrod J.S., Zagadnienia wybrane z praktyki administracyjnej, Kraków 1938.

Leszczyński L., Open Axiology in Judicial Interpretation of Law and Possible Misuse of Discretion, "Studia Iuridica Lublinensia" 2020, vol. 29(3), DOI: https://doi.org/10.17951/sil.2020.29.3.39-54.

Łajszczak S., Rozwój procedur administracyjnych na tle standardów funkcjonowania władzy publicznej, [in:] Kierunki rozwoju prawa administracyjnego. Prace członków i Przyjaciót na 5-lecie Koła Naukowego Prawa Administracyjnego na Uniwersytecie Warszawskim, ed. R. Stankiewicz, Warszawa 2011.

Mincer M., Uznanie administracyjne, Toruń 1983.

Nałęcz A., Uznanie administracyjne a reglamentacja działalności gospodarczej, Warszawa 2010.

Pesce G., Discretionary Power of Public Administration and Control of Public Debt: The Citizen and the Judge between the Law and the Precedent, "Studia Iuridica Lublinensia" 2020, vol. 29(3), DOI: http://dx.doi.org/10.17951/sil.2020.29.3.117-134.

Reiss W., Prawo administracyjne w zarysie, part 1: Nauka administracji, Torun 1946.

Starościak J., Swobodne uznanie władz administracyjnych, Warszawa 1948.

Tarno J.P., Prawo o postepowaniu przed sadami administracyjnymi. Komentarz, Warszawa 2006.

Woś T. (ed.), Knysiak-Molczyk H., Romańska M., Ustawa o postępowaniu przed sądami administracyjnymi. Komentarz, Warszawa 2012.

Wróbel A., [in:] M. Jaśkowska, M. Wilbrandt-Gotowicz, A. Wróbel, Komentarz aktualizowany do ustawy z dnia 14 czerwca 1960 r. - Kodeks postępowania administracyjnego, LEX/el 2019.

Zimmermann M., Pojęcie administracji publicznej a swobodne uznanie, Warszawa 2009.

\section{Legal acts}

Act of 14 June 1960 - Code of Administrative Procedure (Journal of Laws 2021, item 735).

Act of 17 June 1966 on enforcement proceedings in the public administration (Journal of Laws 2020, item 1427, as amended).

Act of 31 January 1980 on the Supreme Administrative Court and on the amendment of the Act Code of Administrative Procedure (Journal of Laws 1980, no. 4, item 8).

Act of 29 August 1997 - Tax Ordinance (Journal of Laws 2020, item 1235, as amended).

Act of 25 July 2002 - Law on the System of Administrative Courts (Journal of Laws 2021, item 137).

Act of 30 August 2002 - Law on Procedure Before Administrative Courts (Journal of Laws 2019, item 2325 , as amended).

Act of 2 April 2009 on Polish citizenship (Journal of Laws 2020, item 347).

Act of 9 April 2015 amending the Act - Law on Procedure Before Administrative Courts (Journal of Laws 2015, item 658).

Constitution of the Republic o Poland of 2 April 1997 (Journal of Laws 1997, no. 78, item 483, as amended).

Regulation of 27 October 1932 on the Supreme Administrative Tribunal (Journal of Laws 1932, no. 94 , item 806 ).

\section{Case law}

Judgement of the Constitutional Tribunal of 10 May 1994, W 7/94, OTK 1994, no. 1, item 23.

Judgement of the Supreme Administrative Court of 11 June 1981, SA 820/81, ONSA 1981, no. 1, item 57.

Judgement of the Supreme Administrative Court of 7 February 2001, I SA/Gd 1507/00.

Judgement of the Supreme Administrative Court of 26 January 2006, II OSK 630/05.

Judgement of the Supreme Administrative Court of 31 January 2006, I FSK 570/03.

Judgement of the Supreme Administrative Court of 16 March 2006, II FSK 493/05. 
Judgement of the Supreme Administrative Court of 13 November 2007, II FSK 1353/06. Judgement of the Supreme Administrative Court of 30 October 2009, I FSK 804/08. Judgement of the Supreme Administrative Court of 26 August 2010, II FSK 689/09. Judgement of the Supreme Administrative Court of 29 June 2011, II FSK 227/10. Judgement of the Supreme Administrative Court of 27 February 2013, II FSK 1351/11. Judgement of the Supreme Administrative Court of 15 March 2013, II FSK 1535/11. Judgement of the Supreme Administrative Court of 17 May 2017, II GSK 5349/16. Judgement of the Supreme Administrative Court of 6 October 2017, II FSK 2422/15. Judgement of the Supreme Administrative Court of 7 February 2018, II FSK 3609/15. Judgement of the Supreme Administrative Court of 29 May 2018, II FSK 1431/16. Judgement of the Supreme Administrative Court of 30 May 2018, II FSK 3783/17. Judgement of the Supreme Administrative Court of 6 December 2018, I FSK 1369/16. Judgement of the Supreme Administrative Court of 26 June 2019, II FSK 2414/17. Judgement of the Supreme Administrative Court of 5 September 2019, I OSK 1419/18. Judgement of the Voivodeship Supreme Administrative Court in Rzeszów of 2 July 2019, I SA/Rz $244 / 19$.

\section{ABSTRAKT}

Artykuł ma charakter naukowo-badawczy. Autor, w oparciu o polskie regulacje prawne i orzecznictwo sądów administracyjnych, analizuje problem granic sądowej kontroli podejmowanych przez organy podatkowe decyzji uznaniowych mających za przedmiot zastosowanie ulg w spłacie zobowiązań podatkowych. Można zauważyć, że - mimo podejmowania problematyki uznania administracyjnego w piśmiennictwie naukowym - zagadnienie granic sądowej kontroli w praktyce orzeczniczej sądów administracyjnych ciągle budzi wątpliwości. Zasadnie jest zatem, co jest celem niniejszego opracowania, przeprowadzenie analizy głównych poglądów formułowanych w piśmiennictwie i w orzecznictwie sądowoadministracyjnym w odniesieniu do tego problemu, z punktu widzenia granic sądowej kontroli decyzji uznaniowych. Tezą artykułu jest założenie, że determinowany funkcją uznania administracyjnego charakter decyzji uznaniowych mających za przedmiot zastosowanie ulg w spłacie zobowiązań podatkowych, a także zakreślone ustawowo kryteria sądowej kontroli administracji publicznej ograniczają rolę sądu administracyjnego do zbadania zgodności z prawem procesowym samego postępowania podatkowego poprzedzającego wydanie takiej decyzji oraz do respektowania przez organy podatkowe podstawowych wartości systemu prawa, wyrażonych w Konstytucji RP. Wyznaczają one bowiem granice uznania administracyjnego, wewnątrz których wybór jednego z możliwych rozstrzygnięć pozostaje poza sądową kontrolą administracji. De lega lata nie ma podstaw do tego, aby sądy administracyjne, z zastrzeżeniem respektowania przez organy podatkowe podstawowych wartości systemu prawa, wyrażonych w Konstytucji RP, formułowały oceny co do okoliczności i przyczyn uzasadniających udzielenie albo odmowę udzielenia ulgi podatkowej bądź jej zakresu. Dla orzecznictwa sądowoadministracyjnego przydatna może być zatem koncepcja wewnętrznych i zewnętrznych granic uznania administracyjnego.

Slowa kluczowe: decyzje uznaniowe; granice sądowej kontroli decyzji uznaniowych; organy podatkowe; prawo procesowe; uznanie administracyjne 